\title{
Wax Behavior in Crude Oils by Pour Point Analyses
}

\author{
Lize M. S. L. Oliveira, ${ }^{a, b, \#}$ Rita C. P. Nunes, ${ }^{c}$ Ygor L. L. Ribeiro, ${ }^{a}$ Dayane M. Coutinho, ${ }^{d}$ \\ Débora A. Azevedo, ${ }^{d}$ Júlio C. M. Dias ${ }^{c}$ and Elizabete F. Lucas ${ }^{*, a, c}$ \\ ${ }^{a}$ Laboratório de Macromoléculas e Colóides na Indústria do Petróleo (LMCP), \\ Instituto de Macromoléculas, Universidade Federal do Rio de Janeiro, \\ Av. Horácio Macedo, 2030, Bloco J, 21941-598 Rio de Janeiro-RJ, Brazil \\ ${ }^{b}$ Centro de Pesquisas e Desenvolvimento Leopoldo Américo Miguez de Mello (CENPES), Petrobras, \\ Av. Horácio Macedo, 950, Cidade Universitária, 21941-915 Rio de Janeiro-RJ, Brazil \\ ${ }^{c}$ COPPE/PEMM/LADPOL, Universidade Federal do Rio de Janeiro, \\ Av. Horácio Macedo, 2030, Bloco F, 21941-598 Rio de Janeiro-RJ, Brazil \\ ${ }^{d}$ Laboratório de Apoio ao Desenvolvimento Tecnológico (LADETEC), \\ Instituto de Química, Universidade Federal do Rio de Janeiro, \\ Av. Horácio Macedo, 1281, 21941-598 Rio de Janeiro-RJ, Brazil
}

\begin{abstract}
Crude oils containing large quantities of waxes, and in situations where sudden temperature drops occur, a crystalline network can be formed, generating flow difficulties in production, transfer and offloading lines. Despite the scientific and economic importance of this phenomenon, correlations between the behavior of petroleum in relation to its pour point are scarce in the literature. In this work, nine crude oil samples were characterized regarding density, water content, wax fraction (one- and two-dimensional chromatography), pour point, yield stress and wax appearance temperature. The results showed that the storage conditions and oil characteristics had a strong influence on the pour point. Yield stress was influenced by initial temperature of the sample, cooling rate and shear rate during cooling. Finally, the content of aromatic compounds in oil with low concentration of $n$-alkanes can contribute to increase the pour point.
\end{abstract}

Keywords: crude oils, pour point, yield stress, gas chromatography, waxes

\section{Introduction}

In the reservoir, crude oil behaves as a Newtonian fluid, since the waxes with high molar mass are in solution, causing the oil to act as a monophasic liquid, i.e., in laminar flow, in which the viscosity is only a function of temperature, independent of the shear rate. ${ }^{1,2}$ As soon as the oil leaves the reservoir and flows through the line at a lower temperature, the temperature gradient between the cold wall of the pipe and the hot oil causes the waxes to precipitate. When the temperature of a crude oil containing high quantities of waxes drops suddenly, a crystalline network forms, impeding its flow in production, transfer or offloading lines. The precipitated waxes, when aggregating, can alter the flow, resulting in non-Newtonian behavior of the oil. The presence of wax crystals can also

*e-mail: elucas@metalmat.ufrj.br

\#On leave. lead to an increase in viscosity, requiring application of a much higher pressure to assure continued flow. ${ }^{3-9}$ Other components present in petroleum, such as polar compounds, resins and asphaltenes, can co-precipitate with the wax crystals, generating sludges that are hard to remove. ${ }^{10,11}$ In general, organic compounds can be used to prevent wax deposition. ${ }^{12,13}$

The determination of several parameters, such as the wax appearance temperature (WAT), crystallization enthalpy (using microcalorimetry), pour point and yield stress, can help the evaluation of the crystallization and deposition of waxes in crude oil. ${ }^{12,14-16}$

The WAT is the temperature at which the first wax crystals start to form under cooling. It can be measured by differential scanning calorimetry (DSC), a technique also applicable to determine the variation of enthalpy of the crystallization process. Microcalorimetry is significantly more sensitive,${ }^{17}$ revealing the transition more clearly, 
besides allowing observation of other more discrete transitions that cannot be detected by calorimetry. It can also be used for tests under pressure, thus more faithfully reproducing real conditions. ${ }^{12,14,18}$

Another procedure used to assess wax deposition involves determining the pour point, which is the lowest temperature at which the oil is able to flow only under the action of gravity. A pour point above the ambient temperature is an indication of the presence of large amounts of paraffinic hydrocarbons with long chains, known as waxes. The exception is heavy oils, which have high pour points due to the large quantity of asphaltenes and resins in their composition. ${ }^{19-22}$ Knowledge of the pour point is important because the conditions for pumping, storage and transfer of oil in pipelines and tanks are defined based on this parameter and the viscosity.

The yield stress is one of the properties that helps to describe and to understand the complex behavior of the gelled structure formed when an oil with high paraffin content is cooled under a static condition. The term yield stress denotes the minimum stress that must be applied to a determined material to produce a shear flow. It is a rheological property of petroleum that represents the transition between the elastic solid behavior of a gelled oil and its behavior as a viscous liquid when a production shutdown occurs. ${ }^{23-25}$

Gas chromatography (GC) has been used to determine petroleum compounds. ${ }^{26}$ However, two-dimensional gas chromatography $(\mathrm{GC} \times \mathrm{GC})$ has been used to better identify many kind of organic compounds. ${ }^{27,28}$

In this work, we characterized and quantified the waxes present in crude oil samples using traditional methods, such as one-dimensional gas chromatography, and recently developed chromatographic methods, such as comprehensive two-dimensional gas chromatography, seeking to correlate the distribution of the wax chains with the pour point of the oil samples.

\section{Experimental}

Materials

Nine samples of crude oil, called here AP01, AP02, AP03, AP04, AP05, AP06, AP07, AP08 and AP09, were used for the main study. Four crude oil samples, called here SAMG, SAMM, SAMS and SAMU, were used to evaluate two pour point methods (ASTM D97 ${ }^{29}$ and ASTM D5853 $3^{30}$ standards). Nine crude oil samples, named here Petro1, Petro2, Petro3, Petro4, Petro5, Petro6, Petro7, Petro8 and Petro9 (all collected at three different points of primary processing), were used to evaluate the influence of thermal history on the pour point results following ASTM D97. ${ }^{29}$ All crude oil samples were provided by the Petrobras Research Center (CENPES), Rio de Janeiro, Brazil. 99.5\% toluene, supplied by Vetec Química Fina Ltda, Duque de Caxias, Brazil, was distilled at $110{ }^{\circ} \mathrm{C},{ }^{31}$ while $99.9 \%$ cyclohexane, $99.9 \%$ dichloromethane and $95 \% n$-hexane were supplied by Tedia Brasil Ltda., Rio de Janeiro, Brazil. Activated aluminum oxide (150 mesh) and silica gel pore size $30 \AA$ (75-150 $\mu \mathrm{m}$; 100-200 mesh) were supplied by Sigma-Aldrich, São Paulo, Brazil. Silica gel pore size $60 \AA$ (40-63 $\mu \mathrm{m} ; 230-400 \mathrm{mesh}$ ) and silica gel pore size $60 \AA$ (63-200 $\mu \mathrm{m}$; 70-230 mesh) were supplied by SiliCycle Inc, Quebec, Canada. Helium (99.9999\% purity) was purchased from Linde Gas Ltda., Rio de Janeiro, Brazil. Cholestane- $\mathrm{D}_{6}$, dibenzothiophene- $\mathrm{D}_{8}$, hexadecane- $\mathrm{D}_{34}$, pyrene- $\mathrm{D}_{10}$, pristane- $\mathrm{D}_{40}$ and tetracosane- $\mathrm{D}_{50},>97 \%$ purity, were purchased from CDN Isotopes, Quebec, Canada.

\section{Density}

In an Anton Paar DMA 4500M densimeter, a small quantity of oil was inserted in a cell (U-shaped tube) with controlled temperature. The oscillation frequency was recorded and the density of the sample was calculated by using cell constants, previously determined by measuring the oscillation frequency of calibration fluids with known densities. In the petroleum industry, the density of crude oils is usually given in ${ }^{\circ} \mathrm{API}$, since this permits better evaluation of the difference of density between oils. The ${ }^{\circ} \mathrm{API}$ is given by $(141.5 / \mathrm{dR})-131.5$, where $\mathrm{dR}$ is the ratio between the specific mass of the oil and the specific mass of water, both measured at $15^{\circ} \mathrm{C} .{ }^{32}$

\section{Water content (Karl Fischer method)}

The water content of the crude oil samples was determined based on the ASTM D4377-00 standard..$^{33}$ A known quantity of sample was added to the titration jar, already containing a solution of chloroform and methanol in proportion of 3:1. Using a specific Karl Fischer reagent for titrant, the quantity of water present in the sample was determined and reported as $\% \mathrm{~m} / \mathrm{m}$. The device used was a Metrohm 841 Titrando, with double platinum wire electrode, which identifies the presence of water in the medium by measuring conductivity.

\section{Crude oil fractionation}

Oil samples (ca. $200 \mathrm{mg}$ ) were fractionated and the saturated fraction was ascertained through liquid chromatography under vacuum, using as stationary phase: 
(i) silica gel pore size $60 \AA$ (40-63 $\mu \mathrm{m}$; 230-400 mesh); (ii) silica gel pore size $60 \AA$ (63-200 $\mu \mathrm{m}$; 70-230 mesh); (iii) silica gel pore size $30 \AA$ ( $75-150 \mu \mathrm{m} ; 100-200$ mesh); and (iv) activated aluminum oxide (150 mesh). The saturated hydrocarbon fraction was eluted using $n$-hexane $(250 \mathrm{~mL})$. The solvent was evaporated under nitrogen gas flux. $^{34}$

\section{One-dimensional gas chromatography}

The whole crude oil samples were diluted with $\mathrm{CS}_{2}$ at $2 \% \mathrm{~m} / \mathrm{m}$. The reference $n$-alkane sample was a mixture of $n$-alkanes in the range $\mathrm{C}_{5}$ to $\mathrm{C}_{120}$, and it was also prepared with $\mathrm{CS}_{2}$. The chromatographic system used was an Agilent Technologies $6890 \mathrm{~N}$ Network GC system. The injector temperature program was from 50 to $430{ }^{\circ} \mathrm{C}$ at $15^{\circ} \mathrm{C} \mathrm{min}^{-1}$ and held at $430{ }^{\circ} \mathrm{C}$ for $26 \mathrm{~min}$. The $\mathrm{GC}$ oven temperature program was: 20 to $430{ }^{\circ} \mathrm{C}$ at $10^{\circ} \mathrm{C} \mathrm{min}^{-1}$ and held at $430^{\circ} \mathrm{C}$ for $5 \mathrm{~min}$. The detector temperature was set at $430{ }^{\circ} \mathrm{C}$. Helium was used as carrier gas at a constant flow rate of $22.5 \mathrm{~mL} \mathrm{~min}^{-1}$ and the injected volume was $1.0 \mu \mathrm{L} .{ }^{35}$

The saturated fractions were analyzed by gas chromatography with flame ionization detection (GC-FID). The injector temperature program was from 100 to $340{ }^{\circ} \mathrm{C}$ at $15^{\circ} \mathrm{C} \mathrm{min}^{-1}$ and held at $340{ }^{\circ} \mathrm{C}$ for $5 \mathrm{~min}$. The GC oven temperature program was 80 to $340{ }^{\circ} \mathrm{C}$ at $8{ }^{\circ} \mathrm{C} \mathrm{min}^{-1}$ and held at $340{ }^{\circ} \mathrm{C}$ for $7 \mathrm{~min}$. The detector was at $340^{\circ} \mathrm{C}$. Helium was used as carrier gas at a constant flow rate of $5 \mathrm{~mL} \mathrm{~min}{ }^{-1}$, and the injected volume was 1.0 $\mu \mathrm{L}$. Linear, iso and cycloparaffins were calculated by ASTM D5442. ${ }^{36}$

\section{Comprehensive two-dimensional chromatography time-of- flight mass spectrometry (GC×GC-TOFMS)}

Approximately $10.0 \mathrm{mg}$ of each crude oil sample was weighed using an analytical balance and dissolved with a mixture containing internal standards and dichloromethane. The GC $\times$ GC-TOFMS system used was a Pegasus 4D (Leco, St. Joseph, MI, USA), which is an Agilent Technologies 7890 GC (Palo Alto, CA, USA) equipped with a Pegasus H11 time-of-flight mass spectrometer. The GC columns consisted of a DB-17 (Agilent Technologies, Palo Alto, CA, USA) with $50 \%$ phenyl-50\% methylsiloxane (30 $\mathrm{m} \times 0.25 \mathrm{~mm}$ i.d., $0.25 \mu \mathrm{m} \mathrm{df})$ as the first dimension column (1D) and a DB-5 (Agilent Technologies, Palo Alto, CA, USA) with 5\% phenyl-95\% methylsiloxane $(1.5 \mathrm{~m} \times 0.18 \mathrm{~mm}$ i.d., $0.18 \mu \mathrm{m} \mathrm{df})$ as the second dimension column (2D). The injections were performed in a splitless mode of $0.5 \mu \mathrm{L}$ at $310{ }^{\circ} \mathrm{C}$ using a purge time of $60 \mathrm{~s}$ and a purge flow of $5 \mathrm{~mL} \mathrm{~min}^{-1}$. Helium (99.9999\% purity) was used as carrier gas at a constant flow rate of $1.0 \mathrm{~mL} \mathrm{~min}^{-1}$. The oven temperature program was $40{ }^{\circ} \mathrm{C}$ for $5 \mathrm{~min}$ and ramped up to $330{ }^{\circ} \mathrm{C}$ at $3{ }^{\circ} \mathrm{C} \mathrm{min}{ }^{-1}$. The temperature of the secondary oven was $5{ }^{\circ} \mathrm{C}$ higher than that of the primary oven. Modulation period was $9 \mathrm{~s}$, with $4.5 \mathrm{~s}$ hot-pulse duration and modulator temperature $30{ }^{\circ} \mathrm{C}$ higher than the primary oven temperature. The MS transfer line was maintained at $280^{\circ} \mathrm{C}$, and the TOFMS was operated in the electron ionization mode with a collected mass range of $\mathrm{m} / \mathrm{z} 40-650$. The ion source temperature was $230^{\circ} \mathrm{C}$, the detector was operated at $-1400 \mathrm{~V}$, with electron energy $70 \mathrm{eV}$, and an acquisition rate of 100 spectra s${ }^{-1} \cdot{ }^{37}$ GC $\times$ GC-TOFMS data acquisition and processing were performed using the ChromaTOF® software version 4.51 (Leco, St. Joseph, MI, USA). After data acquisition, samples were submitted to a data-processing method in which individual peaks were automatically detected based on a 50:1 signal-to-noise ratio.

Identification was performed by comparing the mass spectra obtained with the NIST Mass Spectral Library software (NIST 08, software version: 2.0) for correct matching, in addition to the retention times. The hydrocarbon classes were analyzed in extracted ion chromatogram (EIC) mode using $\mathrm{m} / \mathrm{z} 85$ ( $n$-alkanes), 57 (branched alkanes), 83 (alkyl-cyclohexanes), 69 (alkylcyclopentanes), 137 (alkyl-decalins), 191 (tri-, tetra-, and pentacyclic terpanes), 91 (alkylbenzenes), 128 (alkylnaphthalenes), 178 (alkyl-phenanthrenes) and 166 (alkyl$9 H$-fluorenes). The semi-quantification was performed by classifications for each sample based on the delimitation of regions for the main hydrocarbon classes. Total ions chromatogram (TIC) was used to obtain the total area and the classes are divided into $n$-alkanes, branched alkanes, monocyclic, bicyclic and polycyclic hydrocarbons, alkylbenzenes, alkyl-naphthalenes, alkylphenanthrenes and alkyl-9H-fluorenes. For each class, a specific internal standard was applied, e.g., $n$-hexadecane- $\mathrm{D}_{34}$ for the saturated hydrocarbon classes and pyrene- $\mathrm{D}_{10}$ for the aromatic hydrocarbons classes. ${ }^{38}$

\section{Analyses of pour point}

The tests were performed according to ASTM D97, ${ }^{29}$ with some adaptations. The determination of pour point is basically a manual method involving the use of a thermometer to read the system's temperature and check the fluidity of the system after every temperature reduction of $3{ }^{\circ} \mathrm{C}$. The no-flow temperature is recorded when the system ceases flowing when being observed in the horizontal position for $5 \mathrm{~s}$. The flow point was reported as the no-flow temperature plus $3{ }^{\circ} \mathrm{C}$. 
For comparison of the results, the ASTM D5853 standard ${ }^{30}$ was also used. In this standard, the pour point is represented by a temperature range. Two measures are obtained, the maximum pour point and the minimum pour point. The maximum pour point (determined in a procedure where crystallization of the waxes is encouraged by applying lateral friction of the test tube with a glass rod before starting the test) was measured as described above in ASTM D97, ${ }^{29}$ while the minimum pour point (with a procedure that discourages crystallization) was determined by submitting the sample to initial thermal treatment, consisting of heating in a pressure cell at $105 \pm 2{ }^{\circ} \mathrm{C}$ for $1 \mathrm{~h}$ followed by cooling to a temperature above the pour point before analysis. The test procedure was the same as that previously described for ASTM D97. ${ }^{29}$ The readings were performed at temperature intervals of $3{ }^{\circ} \mathrm{C}$ and the value obtained was increased by $3{ }^{\circ} \mathrm{C}$.

\section{Determination of wax appearance temperature (WAT)}

The microcalorimetry tests were conducted in a Setaram $\mu \mathrm{DSCIII}$ instrument, using a Hastelloy C276 cell. The tests were performed with approximately $400 \mathrm{mg}$ of sample and undecane as reference. The initial crystallization temperature was obtained with tests having the following program: heating of the samples from room temperature to $80{ }^{\circ} \mathrm{C}$ at a heating rate of $1{ }^{\circ} \mathrm{C} \mathrm{min}-1$; holding the temperature at $80{ }^{\circ} \mathrm{C}$ for $15 \mathrm{~min}$; cooling to $-10{ }^{\circ} \mathrm{C}$ at a cooling rate of $0.48{ }^{\circ} \mathrm{C} \mathrm{min}^{-1}$; holding the temperature at $-10{ }^{\circ} \mathrm{C}$ for $15 \mathrm{~min}$; and heating to $30^{\circ} \mathrm{C}$ at a heating rate of $1{ }^{\circ} \mathrm{C} \mathrm{min}-1$. Based on the curve of heat flow as a function of temperature, the WAT was determined as the onset temperature of the first exothermic peak.

\section{Yield stress}

The yield stress was measured with a Haake Mars III rheometer coupled to a microcomputer and a Thermo Haake bath, with a set of parallel plate sensors with diameter of $35 \mathrm{~mm}$, using oscillatory rheology. This set of parallel plates (PP35) was positioned with spacing of $1.2 \mathrm{~mm}$. A $2.0 \mathrm{~mL}$ aliquot of previously heated crude oil was injected between the sensors using a syringe with steel needle at the initial testing temperature. After positioning the sample, the set of sensors was covered with a split cover to reduce evaporation of the light fractions during the test. The sample, previously heated for $1 \mathrm{~h}$ at $80^{\circ} \mathrm{C}$, was kept heated under stirring at a temperature of $60{ }^{\circ} \mathrm{C}$ and submitted to the standard test in the rheometer, as follows: pre-shear of the sample at $45^{\circ} \mathrm{C}$ for $15 \mathrm{~min}$ at a rate of $10 \mathrm{~s}^{-1}$; cooling of the sample from 45 to $4{ }^{\circ} \mathrm{C}$, under static conditions, at a cooling rate of $0.8{ }^{\circ} \mathrm{C} \mathrm{min}-1$; positioning the sensor at the standard distance for analysis $(1 \mathrm{~mm})$ with an approach velocity of $0.04 \mathrm{~mm} \mathrm{~min}^{-1}$; stabilization of the sample for $15 \mathrm{~min}$ at $4{ }^{\circ} \mathrm{C}$; application of rising stress steps in oscillatory mode (logarithmic increment from $10^{-1}$ to $10^{4} \mathrm{~Pa}$ with duration of $1 \mathrm{~h}, 120$ steps per decade, and frequency of $1 \mathrm{~Hz}$ ). Since the paraffinic gel formed can present properties similar to those of a solid, i.e., elastically deform when submitted to low shear stress, it will only start flowing when the plastic deformation caused by mechanical stress is greater than the yield stress. By considering a balance of forces, it can be demonstrated that the minimum pressure $\left(\Delta \mathrm{P}_{\text {min }}\right)$ able to start the flow of a gelled petroleum sample in the tube is given by equation 1 :

$\Delta \mathrm{P}_{\min }=\frac{4 \mathrm{~L}}{\mathrm{D}} \tau_{0}$

where $\mathrm{L}$ is the length and $\mathrm{D}$ the diameter of the tube, and $\tau_{0}$ is the yield stress. ${ }^{39}$

\section{Results and Discussion}

\section{Characterization and evaluation of the crude oil samples}

The nine oil samples were characterized regarding density, water content, pour point, wax appearance temperature (WAT), yield stress, mass of saturates, content of $n$-alkanes, isoalkanes + cycloalkanes (UCM) by one-dimensional gas chromatography (GC) in the $\mathrm{C}_{15}-\mathrm{C}_{44}$ range; contents of branched alkanes, cycloalkanes and some aromatic compounds in relevant abundance, by twodimensional gas chromatography (GC $\times$ GC-TOFMS) in the $\mathrm{C}_{6}-\mathrm{C}_{40}$ range. The samples were also classified according to the $\mathrm{K}_{\mathrm{UOP}}$ characterization factor. This is a factor proposed by Universal Oil Products (UOP) to classify petroleum according to its nature, as paraffinic $\left(\mathrm{K}_{\mathrm{UOP}} \geq 12.5\right)$, naphthenic $\left(\mathrm{K}_{\mathrm{UOP}}<11.5\right)$, intermediate $\left(11.5 \leq \mathrm{K}_{\mathrm{UOP}} \leq 12.1\right)$ or aromatic $\left(\mathrm{K}_{\mathrm{UOP}} \leq 10\right)$. $\mathrm{K}_{\mathrm{UOP}}=(\mathrm{BT})^{1 / 3} / \mathrm{d}$, where $\mathrm{BT}$ is the mean molar boiling temperature in degrees Rankine $\left[\left({ }^{\circ} \mathrm{C}+273.15\right) \times 95\right]$ and $\mathrm{d}$ is the $15 / 15^{\circ} \mathrm{C}$ density. ${ }^{40}$ The data are compiled in Table 1. The results show that the oil samples are relatively distinct, as indicated by the different density values ( $\left.{ }^{\circ} \mathrm{API}\right)$ found.

With respect to yield stress, this represents the solid-liquid transition of the structured material and is determined by the intersection of the G' (elastic modulus) and G" (viscous modulus) moduli in the graph of these parameters in function of the shear stress applied. In oscillatory rheology, when a variable stress is applied to the sample, gelled fluids have values of G' higher than G" at low stresses, showing a predominantly solid 
Table 1. Characterization data of the crude oil samples

\begin{tabular}{|c|c|c|c|c|c|c|c|c|c|c|}
\hline \multicolumn{2}{|l|}{ Sample } & AP01 & $\mathrm{AP} 02$ & AP03 & AP04 & AP05 & AP06 & AP07 & AP08 & AP09 \\
\hline \multicolumn{2}{|l|}{${ }^{\circ} \mathrm{API}$} & 27 & 30 & 27.4 & 31 & 17.3 & 14.8 & 36 & 28.9 & 23 \\
\hline \multicolumn{2}{|c|}{ Karl Fischer $/ \% \mathrm{~m} / \mathrm{m}$} & 0.05 & 0.03 & 0.50 & 0.03 & 0.60 & 0.09 & 0.45 & 0.04 & 0.01 \\
\hline \multicolumn{2}{|c|}{ Characterization factor $\mathrm{K}_{\mathrm{UOP}}$} & 11.8 & 12.0 & 11.8 & 12.0 & 11.6 & 11.7 & $>12.6$ & 11.9 & 11.9 \\
\hline \multicolumn{2}{|c|}{ Yield stress at $4{ }^{\circ} \mathrm{C} / \mathrm{Pa}$} & 7.2 & 36.6 & 0.7 & 1.7 & 0 & 0 & $>10,000$ & 0 & 4.2 \\
\hline \multirow[t]{2}{*}{ ASTM D $97^{29}$} & pour point $/{ }^{\circ} \mathrm{C}$ & -6 & 12 & $<-24$ & 6 & -6 & 3 & 36 & -15 & 24 \\
\hline & solidification $/{ }^{\circ} \mathrm{C}$ & -9 & 9 & $<-24$ & 3 & -9 & 0 & 33 & -18 & 21 \\
\hline \multirow[t]{2}{*}{$\mu \mathrm{DSC}$} & $1^{\mathrm{st}} \mathrm{WAT} /{ }^{\circ} \mathrm{C}$ & 39.6 & 35.7 & 16.1 & 33.6 & 19.9 & 19.7 & 55.2 & 40.5 & 40.5 \\
\hline & $2^{\text {nd }} \mathrm{WAT} /{ }^{\circ} \mathrm{C}$ & 20.1 & 22.0 & - & 21.6 & - & - & 41.2 & 18.6 & 18.6 \\
\hline \multicolumn{2}{|c|}{ Mass of saturated fraction } & 87.23 & 101.12 & 74.33 & 85.71 & 103.06 & 76.17 & 102.88 & 69.91 & 77.24 \\
\hline \multirow{32}{*}{ 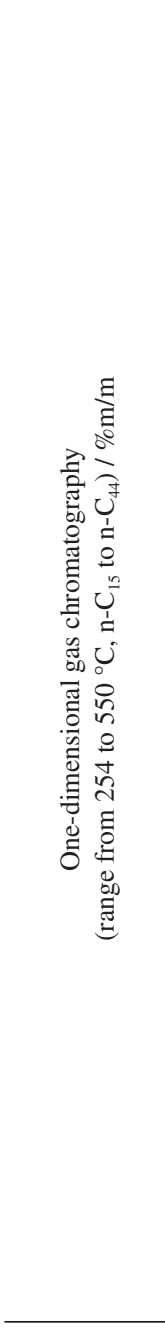 } & $n-\mathrm{C}_{15}$ & 0.08 & 0.19 & 0.05 & 0.08 & 0.00 & 0.00 & 0.19 & 0.05 & 0.09 \\
\hline & $n-\mathrm{C}_{16}$ & 0.19 & 0.28 & 0.17 & 0.19 & 0.00 & 0.00 & 0.48 & 0.14 & 0.17 \\
\hline & $n-\mathrm{C}_{17}$ & 0.24 & 0.34 & 0.23 & 0.30 & 0.00 & 0.00 & 0.69 & 0.20 & 0.28 \\
\hline & $n-\mathrm{C}_{18}$ & 0.23 & 0.28 & 0.24 & 0.28 & 0.00 & 0.00 & 0.79 & 0.23 & 0.26 \\
\hline & $n-\mathrm{C}_{19}$ & 0.32 & 0.34 & 0.30 & 0.34 & 0.00 & 0.00 & 0.98 & 0.28 & 0.33 \\
\hline & $n-\mathrm{C}_{20}$ & 0.25 & 0.23 & 0.23 & 0.24 & 0.00 & 0.00 & 0.90 & 0.23 & 0.25 \\
\hline & $n-\mathrm{C}_{21}$ & 0.20 & 0.22 & 0.17 & 0.22 & 0.00 & 0.00 & 0.94 & 0.17 & 0.23 \\
\hline & $n-\mathrm{C}_{22}$ & 0.19 & 0.21 & 0.15 & 0.22 & 0.00 & 0.00 & 0.91 & 0.17 & 0.25 \\
\hline & $n-\mathrm{C}_{23}$ & 0.20 & 0.20 & 0.15 & 0.21 & 0.00 & 0.00 & 0.94 & 0.17 & 0.23 \\
\hline & $n-\mathrm{C}_{24}$ & 0.18 & 0.20 & 0.13 & 0.21 & 0.00 & 0.00 & 0.87 & 0.15 & 0.23 \\
\hline & $n-\mathrm{C}_{25}$ & 0.19 & 0.20 & 0.14 & 0.20 & 0.00 & 0.00 & 0.95 & 0.17 & 0.24 \\
\hline & $n-\mathrm{C}_{26}$ & 0.17 & 0.20 & 0.12 & 0.21 & 0.00 & 0.00 & 0.83 & 0.16 & 0.25 \\
\hline & $n-\mathrm{C}_{27}$ & 0.15 & 0.18 & 0.11 & 0.19 & 0.00 & 0.00 & 0.81 & 0.14 & 0.23 \\
\hline & $n-\mathrm{C}_{28}$ & 0.17 & 0.18 & 0.13 & 0.18 & 0.00 & 0.00 & 0.71 & 0.18 & 0.23 \\
\hline & $n-\mathrm{C}_{29}$ & 0.12 & 0.16 & 0.09 & 0.16 & 0.00 & 0.00 & 0.67 & 0.11 & 0.18 \\
\hline & $n-\mathrm{C}_{30}$ & 0.08 & 0.12 & 0.06 & 0.13 & 0.00 & 0.00 & 0.53 & 0.07 & 0.14 \\
\hline & $n-\mathrm{C}_{31}$ & 0.05 & 0.11 & 0.04 & 0.11 & 0.00 & 0.00 & 0.45 & 0.03 & 0.12 \\
\hline & $n-\mathrm{C}_{32}$ & 0.04 & 0.08 & 0.03 & 0.08 & 0.00 & 0.00 & 0.34 & 0.03 & 0.09 \\
\hline & $n-\mathrm{C}_{33}$ & 0.03 & 0.06 & 0.03 & 0.06 & 0.00 & 0.00 & 0.23 & 0.03 & 0.06 \\
\hline & $n-\mathrm{C}_{34}$ & 0.02 & 0.05 & 0.02 & 0.05 & 0.00 & 0.00 & 0.19 & 0.02 & 0.05 \\
\hline & $n-\mathrm{C}_{35}$ & 0.02 & 0.03 & 0.02 & 0.03 & 0.00 & 0.00 & 0.14 & 0.02 & 0.03 \\
\hline & $n-\mathrm{C}_{36}$ & 0.01 & 0.02 & 0.01 & 0.02 & 0.00 & 0.00 & 0.11 & 0.01 & 0.02 \\
\hline & $n-\mathrm{C}_{37}$ & 0.01 & 0.01 & 0.01 & 0.02 & 0.00 & 0.00 & 0.06 & 0.01 & 0.02 \\
\hline & $n-\mathrm{C}_{38}$ & 0.01 & 0.01 & 0.01 & 0.01 & 0.00 & 0.00 & 0.06 & 0.01 & 0.01 \\
\hline & $n-\mathrm{C}_{39}$ & 0.00 & 0.01 & 0.00 & 0.00 & 0.00 & 0.00 & 0.04 & 0.00 & 0.01 \\
\hline & $n-\mathrm{C}_{40}$ & 0.00 & 0.00 & 0.00 & 0.00 & 0.00 & 0.00 & 0.03 & 0.00 & 0.00 \\
\hline & $n-\mathrm{C}_{41}$ & 0.00 & 0.00 & 0.00 & 0.00 & 0.00 & 0.00 & 0.04 & 0.00 & 0.00 \\
\hline & $n-\mathrm{C}_{42}$ & 0.00 & 0.00 & 0.00 & 0.00 & 0.00 & 0.00 & 0.02 & 0.00 & 0.01 \\
\hline & $n-\mathrm{C}_{43}$ & 0.00 & 0.00 & 0.00 & 0.00 & 0.00 & 0.00 & 0.02 & 0.00 & 0.00 \\
\hline & $n-\mathrm{C}_{44}$ & 0.00 & 0.00 & 0.00 & 0.00 & 0.00 & 0.00 & 0.01 & 0.00 & 0.00 \\
\hline & total $n$-alkanes & 3.15 & 3.93 & 2.64 & 3.75 & 0.00 & 0.00 & 13.95 & 2.80 & 4.03 \\
\hline & UCM (iso + cycloalkanes) & 34.20 & 30.26 & 29.38 & 29.05 & 23.41 & 24.62 & 26.11 & 30.08 & 23.60 \\
\hline \multirow{10}{*}{ 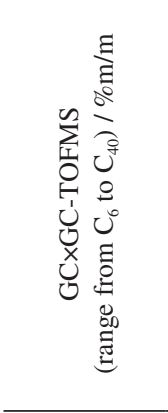 } & branched alkanes & - & 16.4 & - & 20.15 & - & - & 22.95 & - & 20.99 \\
\hline & monocycles & - & 11.33 & - & 11.74 & - & - & 6.88 & - & 6.81 \\
\hline & bicycles & - & 2.87 & - & 2.69 & - & - & 1.33 & - & 1.15 \\
\hline & polycycles & - & 0.6 & - & 0.44 & - & - & 0.13 & - & 0.28 \\
\hline & alkylbenzenes & - & 9.61 & - & 3.58 & - & - & 4.49 & - & 14.78 \\
\hline & alkylnaphthalenes & - & 2.06 & - & 0.82 & - & - & 1.06 & - & 3.41 \\
\hline & alkylphenanthrenes & - & 0.37 & - & 0.12 & - & - & 0.23 & - & 0.57 \\
\hline & alkyl-9H-fluorenes & - & 0.31 & - & 0.09 & - & - & 0.06 & - & 0.06 \\
\hline & total cycles & - & 14.8 & - & 14.87 & - & - & 8.34 & - & 8.24 \\
\hline & total aromatics & - & 12.35 & - & 4.61 & - & - & 5.84 & - & 18.82 \\
\hline
\end{tabular}

DSC: differential scanning calorimetry; WAT: wax appearance temperature; UCM: unresolved complex mixture; GC $\times$ GC-TOFMS: two-dimensional gas chromatography time-of-flight mass spectrometry. 
characteristic. However, this order is altered beyond a critical stress value, and the fluid starts to behave more like a liquid..$^{39}$

The rheogram of sample AP01 in the oscillatory rheometry test, shown in Figure 1, depicts the behavior of the G' and G" curves in function of the oscillatory shear stress. When G' is higher than G" at low stress, the sample behaves as a solid. Then, the value of G' declines (in this case, G" only starts to decline after the two moduli cross) and, finally, G' and G' cross at 7.2 Pa, which represents the solid-liquid transition of the materials submitted to oscillatory forces. When G' is below G', it means that viscous behavior predominates in relation to elastic behavior and the sample does not present yield stress. The yield stress values of all the crude oil samples are presented in Table 1.

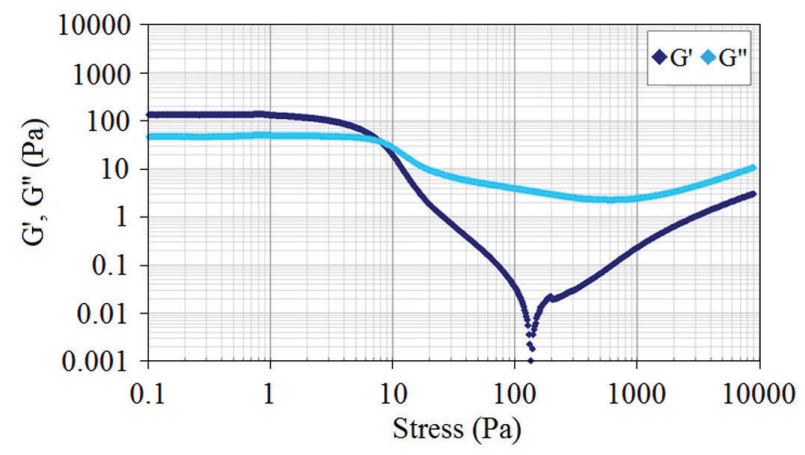

Figure 1. Elastic (G') and viscous (G') modulus in function of stress to determine yield stress for crude oil AP01 measured by the standard method at $4{ }^{\circ} \mathrm{C}$.

With the exception of sample AP07, all the other crude oils had low yield stress values. The yield stress $\left(\tau_{0}\right)$ value obtained for sample AP07 is considered to be high because according to equation 1, depending on the ratio between the length (L) and diameter (D) of the tube, it can require high pressure values $\left(\Delta \mathrm{P}_{\text {min }}\right)$ to assure restart of production after prolonged shutdowns, when the oil typically reaches temperature of $15^{\circ} \mathrm{C}$. In general, oils with high pour point values tend to have higher yield stress values. This was observed for sample AP07, but not for any of the other samples. This can be explained by the fact that both the pour point and yield stress measures are influenced by the initial sample temperature, thermal gradient and cooling rate, among other factors, and the difference in procedure likely caused this small difference in behavior.

To confirm that assumption, we performed another oscillatory rheometry test to measure the yield stress of samples AP02, AP04, AP07 and AP09. In this new test, the initial temperature was equal to that of the pour point test, $45^{\circ} \mathrm{C}$, without previous thermal treatment at $80{ }^{\circ} \mathrm{C}$. The yield stress results, reported in Table 2, showed that when the test was conducted under the same conditions as the pour point test (initial temperature of $45^{\circ} \mathrm{C}$ as indicated by ASTM D97), ${ }^{29}$ the results were more coherent, i.e., the greater the pour point, the higher was the yield stress.

Table 2. Pour point, yield stress with pretreatment and yield stress without pretreatment for oil samples AP02, AP04, AP07 and AP09

\begin{tabular}{lccc}
\hline Oil sample & $\begin{array}{c}\text { Pour point } \\
\left( \pm 3{ }^{\circ} \mathrm{C}\right) /{ }^{\circ} \mathrm{C}\end{array}$ & $\begin{array}{c}\text { Yield stress at } 4{ }^{\circ} \mathrm{C} \\
\left(\mathrm{T}_{\mathrm{i}}=80^{\circ} \mathrm{C}\right) / \mathrm{Pa}\end{array}$ & $\begin{array}{c}\text { Yield stress at } 4{ }^{\circ} \mathrm{C} \\
\left(\mathrm{T}_{\mathrm{i}}=45^{\circ} \mathrm{C}\right) / \mathrm{Pa}\end{array}$ \\
\hline AP02 & 6 & 36.6 & 367.7 \\
AP04 & 12 & 1.7 & 672.8 \\
AP07 & 36 & $>10,000$ & $>10,000$ \\
AP09 & 24 & 4.2 & 3,368 \\
\hline
\end{tabular}

To eliminate any suspicion that the difference between the pour points of the samples was related to some difference in the testing conditions, we evaluated the precision of the methods of determining the pour point and the influence of the thermal treatments on the pour point test result. In a first test, we selected at random four of the oil samples used in this work and performed the pour point tests (ASTM D97 $7^{29}$ and ASTM D5853 $3^{30}$ standards) with four replicates by two technicians, to assess the precision of the laboratory test. The results obtained by each technician are presented in Table 3 separated by "/".

Table 3. Determination of pour point by ASTM D $97^{29}$ and ASTM D $5853^{30}$ standards

\begin{tabular}{|c|c|c|c|c|}
\hline \multirow{2}{*}{$\begin{array}{l}\text { Crude } \\
\text { sample }\end{array}$} & \multirow[b]{2}{*}{ Measure } & \multicolumn{3}{|c|}{ Pour point $/{ }^{\circ} \mathrm{C}$} \\
\hline & & $\begin{array}{l}\text { ASTM } \\
\text { D97 }\end{array}$ & $\begin{array}{c}\text { ASTM } \\
\text { D5853 max }\end{array}$ & $\begin{array}{c}\text { ASTM } \\
\text { D5853 min }\end{array}$ \\
\hline \multirow{4}{*}{ SAMG } & $1^{\mathrm{st}}$ & $-36 /-30$ & $-30 /-27$ & $-45 /-48$ \\
\hline & $2^{\text {nd }}$ & $-33 /-30$ & $-36 /-24$ & $-48 /-48$ \\
\hline & $3^{\text {rd }}$ & $-36 /-30$ & $-33 /-27$ & $-48 /-48$ \\
\hline & $4^{\text {th }}$ & $-36 /-30$ & $-36 /-27$ & $-45 /-51$ \\
\hline \multirow{4}{*}{ SAMM } & $1^{\mathrm{st}}$ & $-24 /-24$ & $-24 /{ }^{a}$ & $-42 /^{\mathrm{a}}$ \\
\hline & $2^{\text {nd }}$ & $-24 / /^{\mathrm{a}}$ & $-24 /{ }^{a}$ & $-33 /^{\mathrm{a}}$ \\
\hline & $3^{\text {rd }}$ & $-27 / /^{a}$ & $-24 / /^{a}$ & $-33 /{ }^{\mathrm{a}}$ \\
\hline & $4^{\text {th }}$ & $-24 / \mathrm{a}$ & $-27 / /^{\mathrm{a}}$ & $-30 / \mathrm{a}$ \\
\hline \multirow{4}{*}{ SAMS } & $1^{\mathrm{st}}$ & $18 / 15$ & $15 / 18$ & $-15 /-12$ \\
\hline & $2^{\text {nd }}$ & $15 / 15$ & $15 / 18$ & $-12 /-12$ \\
\hline & $3^{\text {rd }}$ & $15 / 15$ & $15 / 18$ & $-15 /-12$ \\
\hline & $4^{\text {th }}$ & $18 / 15$ & $15 / 18$ & $-15 /-12$ \\
\hline \multirow{4}{*}{ SAMU } & $1^{\mathrm{st}}$ & $3 / 0$ & $-3 /-3$ & $-15 /-18$ \\
\hline & $2^{\text {nd }}$ & $3 / 0$ & $0 /-3$ & $-12 /-18$ \\
\hline & $3^{\text {rd }}$ & $3 / 0$ & $0 /-3$ & $-15 /-18$ \\
\hline & $4^{\text {th }}$ & $3 / 0$ & $0 /{ }^{\mathrm{a}}$ & $-15 / \mathrm{a}$ \\
\hline
\end{tabular}

${ }^{\mathrm{a}}$ Test not performed due to insufficient quantity of sample. 
According to results obtained for each sample by each method, the maximum difference between the repetitions was $6{ }^{\circ} \mathrm{C}$, with the majority being $3{ }^{\circ} \mathrm{C}$ at most. These values are within the repeatability ranges of the methods used. Between the two test methods, the pour point value obtained by ASTM D9729, in most cases, was near the maximum value obtained by ASTM D5853, ${ }^{30}$ while the minimum value was always substantially below the others, as is inherent to the method.

The differences in the values found by the two technicians were within the intermediate precision range expected for the method and can be considered not significant. Probably the differences in the pour point results found for the crude oil samples studied are not related to fluctuation of the laboratory readings. To assure the reliability of the data generated, we decided to conduct all the pour point tests of the samples in replicate.

After eliminating the hypothesis of repetitiveness problems of the method, we assessed the influence of the thermal history on the pour point results. For that purpose, we carried out a thermal sensitivity test, in which the nine oil samples used (Petro1, Petro2, Petro3, Petro4, Petro5, Petro6, Petro7, Petro8 and Petro9) had been collected at three different points of primary processing (arrival at the platform, exit from the treatment unit and offloading (transfer of the oil from the production platform/vessel to a relief ship)). The results are shown in Table 4.

The pour point of the samples varied according to the temperature to which they were submitted, both in primary processing and in the laboratory simulation. The samples

Table 4. Pour point (ASTM D97) for 27 crude oil samples from 9 production systems

\begin{tabular}{|c|c|c|c|c|c|c|}
\hline \multirow[b]{2}{*}{ Crude oil } & \multirow[b]{2}{*}{ Collect point } & \multicolumn{5}{|c|}{ Pour point $/{ }^{\circ} \mathrm{C}$} \\
\hline & & $\pm 3{ }^{\circ} \mathrm{C}$ & $\begin{array}{c}\text { Cooled at } 4{ }^{\circ} \mathrm{C} \text { for } 48 \mathrm{~h} \\
\left( \pm 3^{\circ} \mathrm{C}\right)\end{array}$ & $\begin{array}{c}\text { Cooled at } 4{ }^{\circ} \mathrm{C} \text { for } 7 \text { days } \\
\qquad\left( \pm 3^{\circ} \mathrm{C}\right)\end{array}$ & $\begin{array}{l}\text { Heated to } 60^{\circ} \mathrm{C} \\
\qquad\left( \pm 3^{\circ} \mathrm{C}\right)\end{array}$ & $\begin{array}{l}\text { Heated to } 105^{\circ} \mathrm{C} \\
\qquad\left( \pm 3^{\circ} \mathrm{C}\right)\end{array}$ \\
\hline & A & 6 & - & - & 3 & -33 \\
\hline \multirow[t]{3}{*}{ Petro1 } & B & 0 & - & - & -15 & -42 \\
\hline & $\mathrm{C}$ & -3 & 6 & 6 & -21 & -39 \\
\hline & A & 0 & - & - & -9 & $<-69$ \\
\hline \multirow[t]{3}{*}{ Petro2 } & B & -3 & - & - & -6 & $<-69$ \\
\hline & $\mathrm{C}$ & -3 & 3 & 0 & -3 & $<-69$ \\
\hline & A & 9 & 3 & - & 9 & -42 \\
\hline \multirow[t]{3}{*}{ Petro3 } & B & 9 & - & - & 6 & -45 \\
\hline & $\mathrm{C}$ & 9 & 9 & 12 & -6 & -42 \\
\hline & A & -24 & - & - & -57 & -57 \\
\hline \multirow[t]{3}{*}{ Petro4 } & B & -12 & - & - & -57 & -51 \\
\hline & $\mathrm{C}$ & -15 & -12 & 0 & -45 & -45 \\
\hline & A & 12 & - & - & 15 & -45 \\
\hline \multirow[t]{3}{*}{ Petro5 } & B & 12 & - & - & 15 & -45 \\
\hline & $\mathrm{C}$ & 0 & -6 & -3 & 0 & -27 \\
\hline & A & -6 & - & - & -33 & -39 \\
\hline \multirow[t]{3}{*}{ Petro6 } & B & 0 & - & - & -54 & -45 \\
\hline & $\mathrm{C}$ & 12 & 12 & 12 & -51 & -45 \\
\hline & A & -18 & - & - & -18 & -24 \\
\hline \multirow[t]{3}{*}{ Petro7 } & B & -9 & - & - & -3 & -24 \\
\hline & $\mathrm{C}$ & -9 & -9 & 0 & 12 & -24 \\
\hline & A & 3 & - & - & 3 & -33 \\
\hline \multirow[t]{3}{*}{ Petro8 } & B & -6 & - & - & -33 & -48 \\
\hline & $\mathrm{C}$ & 6 & 0 & 6 & -15 & -36 \\
\hline & A & 6 & - & - & 6 & -42 \\
\hline \multirow[t]{2}{*}{ Petro9 } & B & 6 & - & - & -6 & -39 \\
\hline & $\mathrm{C}$ & -21 & 3 & -15 & -6 & -42 \\
\hline
\end{tabular}

A: just arriving to the platform; B: close to electrostatic treatment; C: at the offloading. 
that underwent electrostatic treatment were subjected to a temperature that varied from 40 to $90{ }^{\circ} \mathrm{C}$, and in the majority of the cases the samples before treatment presented lower pour points than those that arrived on the platform, as expected. Samples Petro4, Petro6 and Petro7 presented anomalous behavior when comparing the pour point results of each of these systems. The samples from offloading of each system were submitted to prior heating and cooling processes to check the influence of temperature on the pour point. To better visualize the behaviors, the results of the offloading samples are organized in a bar graph (Figure 2). When the samples were heated before the pour point test, the pour point declined in the majority of cases. We can speculate that the rearrangement of the systems due to dissolution of the waxes present in them caused a reduction of the pour point. The majority of the samples that were submitted to cooling before the test showed higher pour point. When the samples were submitted to cooling before the test, in general, the obtained pour point was higher, and the longer the sample remained at low temperature, the stronger this effect was. We observed, therefore, that leaving the samples at rest for $24 \mathrm{~h}$ to erase the thermal history, as specified in ASTM D97 ${ }^{29}$ and ASTM D5853, ${ }^{30}$ was not sufficient for these types of samples.

Thus, the pour points of the crude oils studied were significantly influenced by the thermal variations to which they were submitted, explaining the different pour point

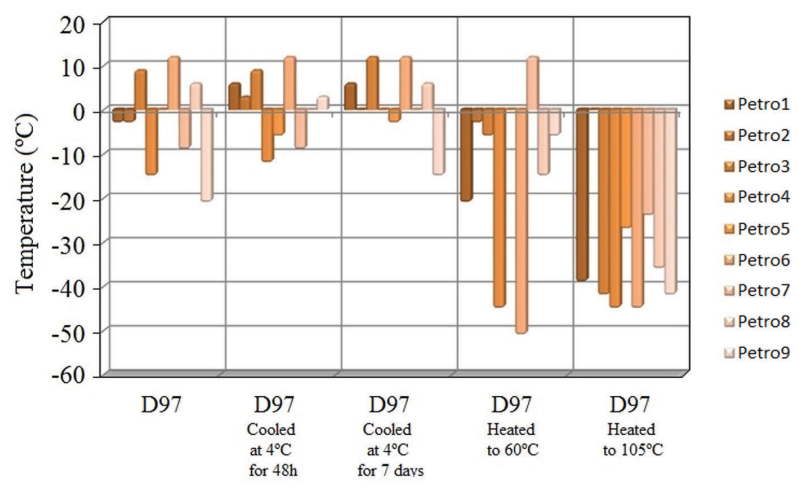

Figure 2. Pour points (ASTM D97) of different crude oil samples submitted to different thermal histories. values found for samples from the same stream (system). We can suppose that this behavior was related to the composition and structure of the wax crystals formed due to cooling of the samples. The samples obtained directly from the reservoir formation, without any thermal treatment, when having waxes in the solid state, were amorphous, while those that had undergone temperature variations presented crystalline structures. These crystalline structures, once formed, if not totally melted served as nucleation points for the growth of new crystals, favoring loss of mobility of the sample. Because of this fact, all the samples analyzed were stored at room temperature, taking care not to heat them before the test or to add them under refrigeration, so that the pour point measured was not influenced by this factor.

The content of paraffins (Table 1) and the distribution profile of the saturated compounds ( $n$-alkanes, isoalkanes and cycloalkanes) were determined by one-dimensional gas chromatography. Figure 3 shows the chromatographic profiles of samples AP02, AP05 and AP07, revealing a difference in the distribution of $n$-paraffins and a more pronounced unresolved complex mixture (UCM) in some samples than others.

Sample AP07 was classified as a paraffinic crude oil $\left(\mathrm{K}_{\mathrm{UOP}}\right.$ factor $\left.>12.6\right)$, containing a quantity of $n$-paraffins in the $\mathrm{C}_{15}-\mathrm{C}_{44}$ range greater than the other samples. In this sample it was also possible to identify the presence of $n$-paraffins with larger chain length than $\mathrm{C}_{37}$, which were not identified or were present only in very small quantities in the other samples.

Samples AP02, AP04 and AP09, considered to be intermediate $\left(\mathrm{K}_{\mathrm{UOP}}\right.$ factors of 12.0, 12.0 and 11.9, respectively), presented a certain similarity in the distribution of $n$-alkanes. For $n$-alkanes greater than $\mathrm{C}_{20}$, sample AP09 presented slightly higher values than AP02 and AP04. The UCM of AP07 was slightly lower than that of AP01, AP02, AP03, AP04 and AP08, but higher than that of AP05, AP06 and AP09. This UCM was found to be composed predominantly of branched and cyclic saturated compounds. Samples AP05 and AP06 were considered biodegraded, with virtually insignificant presence of
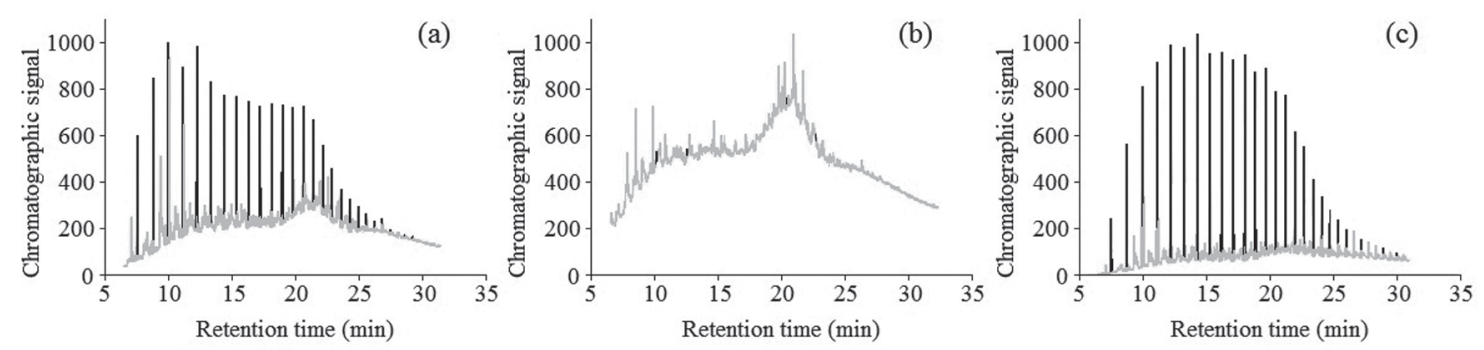

Figure 3. Wax distribution of the crude oils (a) AP02; (b) AP05 and (c) AP07. Black: linear alkanes; gray: iso and cycloalkanes. 
$n$-paraffins in the $\mathrm{C}_{15}-\mathrm{C}_{44}$ range. The chromatographic profiles of samples AP01, AP02, AP03, AP04, AP08 and AP09 were relatively similar to each other.

Samples AP02, AP04 and AP09 were more strongly influenced by the prior temperature in the pour point and yield stress results than AP07. We believe this behavior can be attributed to the fact that the ratio of $n$-alkanes to UCM (iso- and cycloalkanes) was approximately three times higher in crude oil AP07 ( $n$-alkane/UCM $=0.534)$ than in oils AP02, AP04 and AP09, where the $n$-alkane/ UCM ratios were $0.130,0.129$ and 0.171 , respectively (Table 1). Furthermore, AP07 had a much higher content of linear paraffins than the others. Since the structure of linear molecules, such as $n$-paraffins, can favor packing, the formation of a crystalline network is favored any time the temperature declines. With linear molecules, this behavior can be repeated more easily, irrespective of the number of times the temperature is increased and then decreased, causing the flow to stop. In contrast, the structure of nonlinear molecules (iso- and cycloalkanes) can interfere in this packing and hamper the formation of a crystalline network, which can explain the variation of the pour point $\left(3^{\circ} \mathrm{C}\right.$ above the no-flow temperature), depending on how these molecules are arranged during the temperature drop.

Since only four of the nine crude oil samples studied presented relatively high pour points (Table 1), and also considering the complexity of the GCXGC-TOFMS technique, we only characterized samples AP02, AP04, AP07 and AP09 by this method. The samples were analyzed through their total ion chromatograms (TIC) and extracted ion chromatograms (EIC). The classes of saturated compounds that cannot be identified by one-dimensional chromatography (since they elute together) as well as some aromatic compounds could be identified. It is important to mention that by this method, the ion utilized to obtain the EIC is not always the base peak in the mass spectrum, but rather is a characteristic ion for a given family. The ions for determining the EIC were selected to obtain a better visualization of the classes.

The qualitative and semi-quantitative data obtained for samples AP02, AP04, AP07 and AP09, for the classes of compounds that could be identified (isoalkanes, cycloalkanes and some aromatic compounds), were to a certain extent coherent with the data obtained by one-dimensional chromatography regarding pour point and yield stress values. Figure 4 graphically compares the contents of $n$-alkanes identified by the GC-FID technique in the $\mathrm{C}_{15}-\mathrm{C}_{44}$ range and the contents of isoalkanes, cycloalkanes and aromatic compounds that could be identified by $\mathrm{GC} \times \mathrm{GC}-\mathrm{TOFMS}$ in the $\mathrm{C}_{6}-\mathrm{C}_{40}$ range.

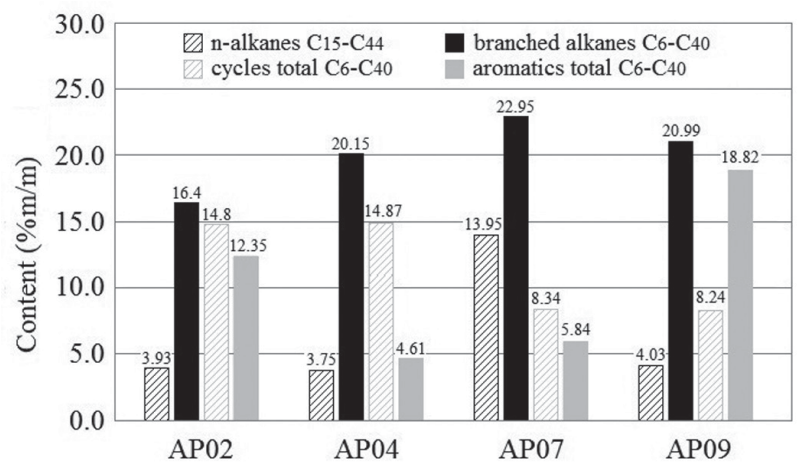

Figure 4. Content of $n$-alkanes by one-dimensional chromatography (GC-FID, $\mathrm{C}_{15}-\mathrm{C}_{44}$ ) and isoalkanes, cycloalkanes and aromatics by twodimensional chromatography (GC $\times$ GC-TOFMS, $\mathrm{C}_{6}-\mathrm{C}_{40}$ ) for AP01, AP04, AP07 and AP09.

The results obtained by one-dimensional chromatography along with the data obtained by two-dimensional chromatography (Figure 4) revealed that crude oil AP07 had the highest content of $n$-alkanes present in the $\mathrm{C}_{15}-\mathrm{C}_{44}$ range (GC-FID) $(13.95 \% \mathrm{~m} / \mathrm{m})$, a level much higher than the other crude oils analyzed $(4.03,3.93$ and $3.75 \% \mathrm{~m} / \mathrm{m}$ for samples AP09, AP02 and AP04, respectively), in line with its very high pour point $\left(36^{\circ} \mathrm{C}\right)$ and greater yield stress (> 10,000 Pa). Sample AP09 presented a slightly higher content of $n$-alkanes than AP02 and AP04, agreeing with the pour point and yield stress results, which were higher for AP09 than for AP02 and AP04.

Sample AP07 also contained the largest quantity of branched alkanes (isoalkanes) in the $\mathrm{C}_{6}-\mathrm{C}_{40}$ range (GC $\times$ GC-TOFMS), with $22.95 \% \mathrm{~m} / \mathrm{m}$, although this was not so different than AP09 $(20.99 \% \mathrm{~m} / \mathrm{m})$ and AP04 $(20.15 \% \mathrm{~m} / \mathrm{m})$. Sample AP02 had the lowest content of isoalkanes $(16.40 \% \mathrm{~m} / \mathrm{m})$. Comparison of the UCM (iso- and cycloparaffins) determined by one-dimensional chromatography with the sum of the isoalkanes and cycloalkanes obtained by two-dimensional chromatography revealed results that were relatively close: for AP02, 30.26 (1D) and $31.20 \% \mathrm{~m} / \mathrm{m}(2 \mathrm{D})$; for AP04, 29.05 (1D) and $35.02 \% \mathrm{~m} / \mathrm{m}$ (2D); for AP07, 26.01 (1D) and $31.29 \% \mathrm{~m} / \mathrm{m}(2 \mathrm{D})$; and for AP09, 23.60 (1D) and $29.23 \% \mathrm{~m} / \mathrm{m}$ (2D). Although one-dimensional chromatography cannot distinguish cyclical from branched compounds, it still produces values having a certain correspondence with those detected by two-dimensional chromatography. The second technique presented slightly higher-contents, which can be explained by its greater detection range $\left(\mathrm{C}_{6}-\mathrm{C}_{40}\right)$ than that of the one-dimensional method $\left(\mathrm{C}_{15}-\mathrm{C}_{44}\right)$. In turn, regarding the levels of naphthenic compounds (cycloalkanes), while oils AP02 and AP04 presented total cycloalkane contents that were close to each other (14.80 and $14.87 \% \mathrm{~m} / \mathrm{m})$, with 
predominance of compounds with only one ring (Figure 4), samples AP07 and AP09 contained lower, but also similar, contents ( 8.34 and $8.24 \% \mathrm{~m} / \mathrm{m}$, respectively), as well as similar distribution by number of rings present (Figure 5). These findings suggest that the higher pour points of these two samples ( 36 and $24{ }^{\circ} \mathrm{C}$, respectively) are also related to the lower levels of naphthenic compounds present.

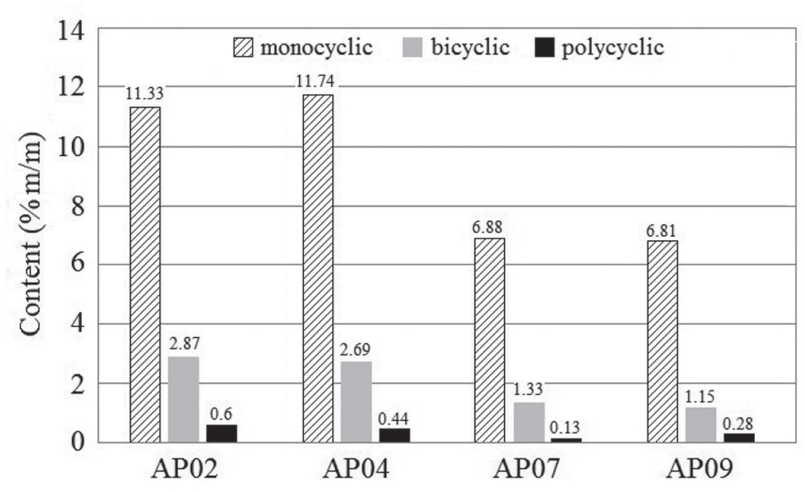

Figure 5. Distribution of naphthenic compounds at the range of $\mathrm{C}_{6}$ to $\mathrm{C}_{40}$, obtained by $\mathrm{GC} \times \mathrm{GC}-\mathrm{TOFMS}$.

Samples AP02 and AP09 were found to have a greater content of aromatic compounds in the $\mathrm{C}_{6}-\mathrm{C}_{40}$ range (alkylbenzenes, alkyl-naphthalenes, alkyl-phenanthrenes and alkyl-9H-fluorenes) than the other two crude oils, with a significant contribution from the alkylbenzene compounds ( 9.61 and $14.78 \% \mathrm{~m} / \mathrm{m}$ for AP02 and AP09, respectively) (Figure 6). Samples AP04 and AP07 had content of aromatics in a narrower range of values and also with predominance of alkylbenzenes ( 3.58 and $4.49 \% \mathrm{~m} / \mathrm{m}$, respectively). The level of aromatic compounds in AP09 was substantially higher than in the others, suggesting that the high pour point of this oil, despite the lower level of $n$-alkanes than in AP07, is related to the presence of aromatic rings. These rings, due to their intermolecular forces, favor gel formation, diminishing the mobility of the system and consequently increasing the pour point. Similar reasoning can be applied to AP02, also

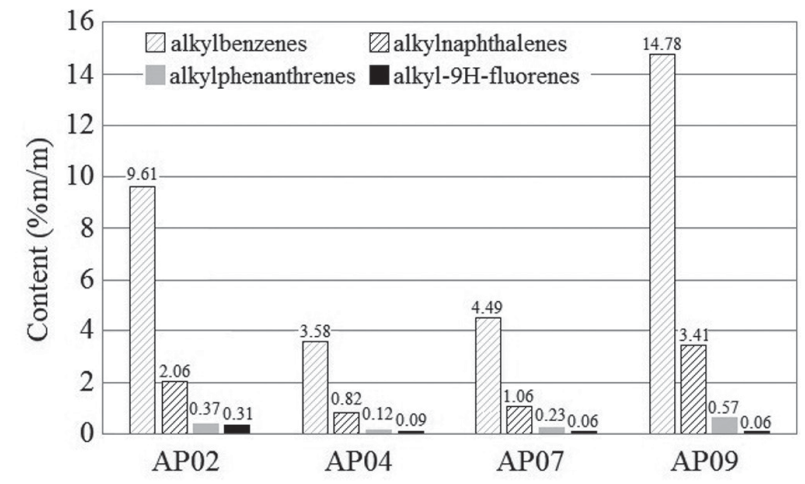

Figure 6. Distribution of aromatic compounds at the range of $\mathrm{C}_{6}$ to $\mathrm{C}_{40}$, obtained by GC $\times$ GC-TOFMS. with a higher content of aromatics than the other two crude oils (AP04 and AP07), but lower than AP09, for this reason having a higher pour point, but one lower than AP09, even with the lower content of $n$-alkanes than in AP07 (Table 1).

Analysis of the distributions of compounds by families based on the combined data generated by the GC-FID and GC $\times$ GC-TOFMS techniques, as shown in Figures 4, 5 and 6, reveals that samples AP02, AP04, AP07 and AP09 contain distinct contents of saturated compounds and aromatic compounds, elucidating the pour point behavior of these crude oils.

\section{Conclusions}

With respect to the pour point measurement, the results show that when the crude oil samples were submitted to higher temperatures before the tests, the pour point tended to diminish, while the opposite occurred when the samples were submitted to lower temperatures before testing. This indicates the need for careful standardization of the sampling and storage conditions.

The yield stress and pour point were both influenced by the initial sample temperature, thermal gradient, cooling rate and shear rate during cooling. In general, oils with high pour point can be expected to have higher yield stress values, but this relationship is only indicative, not direct. When the initial temperature of the oscillatory rheometry and pour point tests were similar, i.e., without prior treatment at $80^{\circ} \mathrm{C}$, according to ASTM D97, the yield stress and pour point results were coherent, namely that the higher the pour point was, the greater was the yield stress.

The understanding of the behavior of the crude oils' pour point in response to variations in processing, transport and storage conditions was improved by characterization of the waxes contained in the samples by chromatographic techniques. The high level of aromatic compounds in the crude oil samples with low content of $n$-alkanes can explain their higher pour point: the presence of aromatic rings, because of the intermolecular forces they exert, can favor gel formation, reducing the system's mobility and hence increasing the pour point.

\section{Acknowledgments}

The authors thank CNPq (307193/2016-0), CAPES, FAPERJ (E-26/201.233/2014), ANP and Petrobras (0050.0086965.13.9) for financial support.

\section{References}

1. Carnahan, N. F.; Pet. Technol. 1989, 41, 1024. 
2. Kelland, M. A.; Production Chemicals for the Oil and Gas Industry; CRC Press: New York, 2009.

3. Elsharkawy, A. M.; Al-Sahhaf, T. A.; Fahim, M. A.; Fuel 2000, 79, 1047.

4. Venkatesan, R.; Singh, P.; Fogler, H. S.; Soc. Pet. Eng. J. 2002, 7, SPE-72237-PA.

5. Azevedo, L. F. A.; Teixeira, A. M.; Pet. Sci. Technol. 2003, 21, 393.

6. Pedersen, K. S.; Rønningsen, H.; Energy Fuels 2003, 17, 321.

7. Paso, K.; Senra, M. Y.; Yi, Y.; Sastry, A. M.; Fogler, H. S.; Ind. Eng. Chem. Res. 2005, 44, 7242.

8. Tinsley, J. F.; Jahnke, J. P.; Adamson, D.; Guo, X.; Amin, D.; Kriegel, R.; Saine, R.; Dettman, H. D.; Prud'Home, R. K.; Energy Fuels 2009, 23, 2056.

9. Espada, J. J.; Coutinho, J. A. P.; Peña, J. L.; Energy Fuels 2010 , 24, 1837.

10. Freund, M.; Csikós, R.; Keszthelyi, S.; Mózes, G.; Paraffins Products; Elsevier: New York, 1982.

11. Santos, J. S. T.; Fernandes, A. C.; Giulietti, M.; J. Pet. Sci. Eng. 2004, $45,47$.

12. Vieira, L. C.; Buchuid, M. B.; Lucas, E. F.; Chem. Chem. Technol. 2008, 2, 211.

13. Gilles, V.; Vieira, M. A.; Lacerda Jr., V.; Castro, E. V. R.; Santos, R. B.; Orestes, E.; Carneiro, J. W. M.; Greco, S. J.; J. Braz. Chem. Soc. 2015, 26, 74.

14. Vieira, L. C.; Buchuid, M. B.; Lucas, E. F.; Energy Fuels 2010, 24, 2213.

15. Lucas, E. F.; Ferreira, L. S.; Khalil, C. N. In Encyclopedia of Polymer Science and Technology; Mark, H. F., ed.; John Wiley \& Sons: New York, 2015, DOI 10.1002/0471440264.pst641.

16. Oliveira, L. M. S. L.; Nunes, R. C. P.; Melo, I. C.; Ribeiro, Y. L. L.; Reis, L. G.; Dias, J. C. M.; Guimarães, R. C. L.; Lucas, E. F.; Fuel Process. Technol. 2016, 149, 268.

17. Carvalho, S. P.; Lucas, E. F.; González, G.; Spinelli, L. S.; J. Braz. Chem. Soc. 2013, 24, 1998.

18. Vieira, L. C.; Buchuid, M. B.; Lucas, E. F.; J. Therm. Anal. Calorim. 2013, 111, 583.

19. Speight, J. G.; Handbook of Petroleum Analysis; John Wiley and Sons, Inc.: New York, 2001.

20. Peyton, K. B.; Nalco Fuel Field Manual; McGraw Hill: New York, 2002.

21. Chen, W. H.; Zhang, X. D.; Zhao, Z. C.; Yin, C. Y.; Fluid Phase Equilib. 2009, 208, 2809.

22. Martínez-Palou, R.; Mosqueira, M. L.; Zapata-Rendón, B.; Mar-Juárez, E.; Bernal-Huicochea, C.; Cruz, J.; J. Pet. Sci. Eng. 2011, 75, 274.

23. Keentok, M.; Rheol. Acta 1982, 21, 325.
24. Chang, C.; Boger, D. V.; Nguyen, Q. D.; Ind. Eng. Chem. Res. 1998, 37, 1551.

25. Visintin, R. F.; Lapasin, R.; Vignati, E.; D’Antona, P.; Lockhart, T. P.; Langmuir 2005, 21, 6240.

26. Frena, M.; Tonietto, A. E.; Madureira, L. A. S.; J. Braz. Chem. Soc. 2013, 24, 1530.

27. Welke, J. E.; Zini, C. A.; J. Braz. Chem. Soc. 2011, 22, 609.

28. Soares, R. F.; Pereira, R.; Silva, R. S. F.; Mogollon, L.; Azevedo, D. A.; J. Braz. Chem. Soc. 2013, 24, 1570.

29. ASTM D97: Standard Test Method for Pour Point of Petroleum Products, American Society for Testing and Materials (ASTM): New York, 2012.

30. ASTM D5853: Standard Test Method for Pour Point of Crude Oils, American Society for Testing and Materials (ASTM): New York, 2011.

31. Morita, T.; Assumpção, R.; Manual de Soluções, Reagentes e Solventes; Blucher: São Paulo, 2007.

32. ISO 12185:1996: Crude Petroleum and Petroleum Products - Determination of Density - Oscillating U-Tube Method, International Organization for Standardization: Geneva, 2001.

33. ASTM D4377-00: Standard Test Method for Water in Crude Oils by Potentiometric Karl Fischer Titration, American Society for Testing and Materials (ASTM): New York, 2011.

34. Vicente, M. A.; Dias, J. C. M.; Tamanqueira, J. B.; Sad, C. M. S.; Fraga, C. J.; Medeiros, E. F.; Neto, R. R.; Castro, E. V. R.; BR Pat. 1020120334879 A2 2014.

35. ASTM D7169: Standard Test Method for Boiling Point Distribution of Samples with Residues such as Crude Oils and Atmospheric and Vacuum Residues by High Temperature Gas Chromatography, American Society for Testing and Materials (ASTM): New York, 2016.

36. ASTM D5442: Standard Test Method for Analysis of Petroleum Waxes by Gas Chromatography, American Society for Testing and Materials (ASTM): New York, 2013.

37. Vanini, G.; Pereira, V. B.; Romão, W.; Gomes, A. O. L.; Oliveira, M. S. L.; Dias, J. C. M.; Azevedo, D. A.; Microchem. J. 2017, 137, 111.

38. Coutinho, D. M.; França, D.; Vanini, G.; Mendes, L. A. N.; Gomes, A. O.; Pereira, V. B.; Ávila, B. M. F.; Azevedo, D. A.; Fuel 2018, 220, 379.

39. Machado, J. C. V.; Reologia e Escoamento de Fluidos: Ênfase na Indústria de Petróleo; Interciência: Rio de Janeiro, 2002.

40. Szklo, A. S.; Fundamentos do Refino de Petróleo; Interciência: Rio de Janeiro, 2005.

Submitted: February 20, 2018 Published online: May 11, 2018 